\title{
GAMBARAN PENYAKIT KARIES GIGI PADA PENGUNJUNG POLIKLINIK GIGI PUSKESMAS SAGERAT KECAMATAN MATUARI KOTA BITUNG
}

\author{
Feibe Bukunusa ${ }^{1)}$, Novarita Mariana Koch ${ }^{2)}$ \\ (1) Dinas Kesehatan Kota Bitung, JL. Sam Ratulangi No.45 Kota Bitung \\ (2) Jurusan Kesehatan Gigi Poltekkes Kemenkes Manado Jl. R.W. Mongisidi Malalayang Manado
}

Email : fbukunusa@gmail.com

\begin{abstract}
ABSTRAK
Pendahuluan : Karies gigi adalah penyakit jaringan gigi yang ditandai dengan kerusakan jaringan, dimulai dari permukaan gigi (pit, fissur, dan daerah interproximal) meluas ke arah pulpa, Karies gigi dapat timbul pada satu permukaan gigi atau lebih dan dapat meluas ke bagian yang lebih dalam dari gigi. Tujuan penelitian ini adalah untuk mengetahui Gambaran Penyakit Karies Gigi Pengunjung Poliklinik Gigi Puskesmas Sagerat selang tahun 2017-2018. Metode : Penelitian ini menggunakan metode deskriptif dengan mengambil data pada buku register pengunjung poliklinik gigi selang tahun 2017-2018. Waktu penelitian pada bulan Mei 2019, tempat penelitian di poliklinik gigi Puskesamas Sagerat Kecamatan Matuari Kota Bitung. Kriteria penelitian yaitu penderita karies gigi yang dibedakan dengan karakteristik umur dan jenis kelamin. Sampel penelitian berjumlah 491 pasien. Instrumen penelitian dari sumber data berupa buku register pengunjung poliklinik gigi Puskesmas Sagerat. Data yang telah dikumpulkan ditabulasi dan disasjikan dalam bentuk tabel distribusi frekuensi persentase. Hasil : Hasil penelitian yang didapat menunjukkan jumlah kunjungan penderita karies gigi tertinggi di tahun 2018 yaitu sebanyak 276 penderita. Jumlah penderita karies gigi berdasarkan kelompok umur yang tertinggi ada pada tahun 2018 yaitu pada kelompok umur $31 \mathrm{~s} / \mathrm{d} 50$ tahun sebanyak 120 penderita $(43,5 \%)$. Distribusi penderita karies gigi berdasarkan jenis kelamin yang tertinggi di tahun 2017 dan 2018 adalah jenis kelamin perempuan sebanyak 116 orang (58,7\%). Berdasarkan kunjungan penderita berdasarkan kasus karies gigi yang tertinggi ada pada tahun 2018 yaitu kasus abses/KMA sebanyak 177 kasus $(64,1 \%)$.
\end{abstract}

\section{Kata Kunci : Karies Gigi, Umur, Jenis Kelamin, Pengunjung Poliklinik Gigi}

\begin{abstract}
Introduction: Dental caries is a dental tissue disease characterized by tissue damage, starting from the tooth surface (pits, fissures, and interproximal areas) extending towards the pulp, dental caries can arise on one or more tooth surfaces and can extend to deeper parts of the tooth. . The purpose of this study was to determine the description of dental caries in the Sagerat Public Health Center Dental Polyclinic between 2017-2018. Methods: This study used a descriptive method by taking data from the dental polyclinic visitor register book between 2017-2018. When the research was in May 2019, the research site was at the dental polyclinic of Puskesamas Sagerat, Matuari District, Bitung City. The research criteria were patients with dental caries, which were differentiated by age and gender characteristics. The research sample was 491 patients. The research instrument from the data source was in the form of a visitor register book for the dental polyclinic of Sagerat Health Center. The data that has been collected is tabulated and presented in the form of a percentage frequency distribution table. Results: The results obtained showed the highest number of dental caries patient visits in 2018, namely 276 patients. The highest number of dental caries sufferers by age group was in 2018, namely in the 31 to 50 years age group as many as 120 patients (43.5\%). The highest distribution of dental caries sufferers by gender in 2017 and 2018 was female as many as 116 people (58.7\%). Based on patient visits based
\end{abstract}


on cases of dental caries, the highest was in 2018, namely cases of abscess / KMA as many as 177 cases $(64.1 \%)$.

Keywords: Dental Caries, Age, Gender, Dental Polyclinic Visitors

\section{PENDAHULUAN}

Sehat adalah suatu keadaan yang sempurna fisik, mental dan sosial, tak hanya bebas dari cacat dan kelemahan (Sriyono, 2005). Kesehatan gigi dan mulut merupakan suatu aktivitas yang mempengaruhi orang-orang untuk bertingkah laku yang baik bagi kesehatan dan meningkatkan kesadaran masyarakat akan kesehatan gigi dan mulut. Di Indonesia penyakit gigi dan mulut terutama karies dan penyakit periodontal, masih banyak diderita penduduk Indonesia baik oleh anak-anak maupun usia dewasa $^{1}$

Riset Kesehatan Dasar (RISKESDAS) tahun 2018 dilaporkan bahwa semua propinsi di Indonesia yang mengalami masalah kesehatan gigi dan mulut 45,3\%, yang menerima perawatan/pengobatan gigi dan mulut hanya $52,9 \% .^{2}$ Masalah kesehatan gigi di Indonesia banyak diderita masyarakat disebabkan karena terabainya kebersihan gigi dan mulut. Kebersihan gigi dan mulut yang terabaikan merupakan salah satu penyebab terjadinya kerusakan pada gigi. Penyakit gigi dan mulut yang paling utama adalah karies gigi dan penyakit periodontal. ${ }^{3}$

Berdasarkan Survei awal di Puskesmas Sagerat, bahwa Poli gigi di Puskesmas Sagerat melaksanakan pelayanan setiap hari Senin sampai Kamis jam pelayanan jam 08.00-14.00, hari Jumat jam 08.00-12.00 dan untuk hari Sabtu jam 08.00-11.00. Data awal yang didapat melalui buku register atau buku laporan di poli gigi puskesmas Sagerat bahwa kunjungan pasien di poli gigi pada bulan Januari-Desember tahun
2017 berjumlah 681 pasien, dan pada bulan Januari-Desember tahun 2018 berjumlah 958 pasien. Dan jumlah kunjungan berdasarkan jenis kelamin perempuan berjumlah 932 pasien dan jenis kelamin laki-laki berjumlah 707 pasien. Sedangkan berdasarkan umur didapati jumlah kunjungan untuk umur 12 - 30 tahun sebanyak 307 pasien, umur 31-50 sebanyak 774 pasien dan umur 51-70 sebanyak 558 pasien. Dari data kasus penderita karies gigi yang ada selama tahun 2017 dan 2018 didapati kasus dengan Karies Dentin sebanyak 10 kasus, Kelainan Pulpa sebanyak 169 kasus dan Abses/KMA sebanyak 312 kasus.

Tujuan Penelitian ini adalah untuk mengetahui gambaran karies gigi pada pengunjung poliklinik Puskesmas Sagerat Kota Bitung selang waktu $2017-2018$.

\section{METODE}

Metode penelitian menggunakan penelitian deskriptif, dengan tujuan mendiskripsikan atau menggambarkan penyakit karies gigi pengunjung poliklinik gigi Puskesmas Sagerat Kecamatan Matuari Kota Bitung pada tahun 2017 dan 2018. Penelitian dilaksanakan bulan Mei 2019 di Puskesmas Sagerat. Populasi dalam penelitian adalah data seluruh penderita karies gigi yang berkunjung di poliklinik gigi Puskesmas Sagerat kecamatan Matuari kota Bitung pada tahun 2017 dan 2018 berjumlah 491 pasien.

Sampel yang di gunakan dalam penelitian ini yaitu total populasi

\section{HASIL}

1. Gambaran Umum Lokasi Penelitian 
Puskesmas Sagerat terletak di Kelurahan Sagerat Weru I Kecamatan Matuari Kota Bitung Propinsi Sulawesi Utara. Puskesmas Sagerat merupakan salah satu institusi pelayanan kesehatan yang berada di wilayah Kecamatan Matuari dan mempunyai wilayah kerja pada 8 Kelurahan dan luas wilayah 33,96 $\mathrm{KM}^{2}$ dengan jumlah penduduk sebanyak 31.244 jiwa yang terdiri dari jenis kelamin Laki-laki sebanyak 15.949 dan jenis kelamin Perempuan sebanyak 15.295, 7.186 KK. Secara geografis Puskesmas Sagerat Kota Bitung memiliki batas wilayah kerja: Sebelah Utara : Kecamatan Ranowulu. Sebelah Timur : Kecamatan Girian. Sebelah Selatan : Laut Maluku. Sebelah Barat : Minahasa Utara.

Puskesmas Sagerat memiliki sarana dan pra sarana berupa 1 Puskesmas Pembantu (Pustu), 8 Pos Kesehatan Desa, 2 Rumah Dinas, 1 Rumah Paramedis, 2 mobil Ambulans, 6 Sepeda motor, 20 Posyandu Balita, 8 Posyandu Usila, dan 66 Kader Kesehatan Desa.

2. Distribusi Penyakit Karies Gigi Pengunjung Poliklinik Gigi Puskesmas Sagerat Tahun 2017-2018

Distribusi penyakit karies gigi pengunjung Poliklinik Gigi Puskesmas Sagerat Tahun 20172018 dapat dilihat pada tabel 1.

Tabel 1. Distribusi Penyakit Karies Gigi Pengunjung Poliklinik Gigi Puskesmas Sagerat

Tahun 2017-2018.

\begin{tabular}{ccc}
\hline Tahun & $\begin{array}{c}\text { Penyakit } \\
\text { Karies Gigi }\end{array}$ & $\begin{array}{c}\text { Persentase } \\
(\boldsymbol{\%})\end{array}$ \\
\hline 2017 & 215 & 43.8 \\
2018 & 276 & 56.2 \\
\hline Total & $\mathbf{4 9 1}$ & $\mathbf{1 0 0}$ \\
\hline
\end{tabular}

Data pada tabel 1 menunjukkan bahwa jumlah penyakit karies gigi tertinggi tahun 2018 sebanyak 276 orang $(56,3 \%)$.
3. Distribusi Penyakit Karies Gigi Berdasarkan Umur

Distribusi penyakit karies gigi berdasarkan umur dapat dilihat pada tabel 2.

Tabel 2. Distribusi Penyakit Karies Gigi Berdasarkan Umur

\begin{tabular}{ccccc}
\hline \multirow{2}{*}{$\begin{array}{c}\text { Umur } \\
\text { (Thn) }\end{array}$} & \multicolumn{3}{c}{ Tahun } \\
\cline { 2 - 5 } & Karies & \% & Karies & \% \\
\hline $12-30$ & 69 & 32 & 89 & 32.2 \\
$31-50$ & 94 & 43.8 & 120 & 43.5 \\
$51-70$ & 52 & 24.2 & 67 & 24.3 \\
\hline Total & $\mathbf{2 1 5}$ & $\mathbf{1 0 0}$ & $\mathbf{2 7 6}$ & $\mathbf{1 0 0}$ \\
\hline
\end{tabular}

Distribusi penderita karies gigi berdasarkan data pada tabel 2 bahwa yang data tertinggi berumur 31-50 tahun di tahun 2018 sebanyak 120 orang $(43,5 \%)$

4. Distribusi Penyakit Karies Gigi Berdasarkan Jenis Kelamin

Distribusi penyakit karies gigi berdasarkan jenis kelamin dapat dilihat pada tabel 3 berikut ini:

Tabel 3. Distribusi Penyakit Karies Gigi Berdasarkan Jenis Kelamin

\begin{tabular}{ccccc}
\hline \multirow{2}{*}{ Jenis } & \multicolumn{3}{c}{ Tahun } \\
\cline { 2 - 5 } Kelamin & \multicolumn{2}{c}{$\mathbf{2 0 1 7}$} & \multicolumn{2}{c}{$\mathbf{2 0 1 8}$} \\
\cline { 2 - 5 } & Karies & \% & Karies & \% \\
\hline Laki-laki & 99 & 46 & 114 & 41.3 \\
Perempuan & 116 & 54 & 162 & 58.7 \\
\hline Total & $\mathbf{2 1 5}$ & $\mathbf{1 0 0}$ & $\mathbf{2 7 6}$ & $\mathbf{1 0 0}$ \\
\hline
\end{tabular}

Berdasarkan data pada tabel 3 menunjukkan bahwa distribusi penyakit karies gigi berdasarkan jenis kelamin yang tertinggi pada tahun 2018 yaitu perempuan sebanyak 162 orang $(58,7 \%)$.

5. Distribusi Penyakit Karies Gigi Berdasarkan Kasus

Distribusi kunjungan penyakit karies gigi berdasarkan kasus dapat dilihat pada tabel 4 . 
Tabel 4. Distribusi Penyakit Karies Gigi Berdasarkan Kasus

\begin{tabular}{ccccc}
\hline Kasus & \multicolumn{4}{c}{ Tahun } \\
\cline { 2 - 5 } Karies Gigi & \multicolumn{2}{c}{$\mathbf{2 0 1 7}$} & \multicolumn{2}{c}{$\mathbf{2 0 1 8}$} \\
\cline { 2 - 5 } & $\mathbf{n}$ & \% & n & \% \\
\hline $\begin{array}{c}\text { Karies } \\
\text { Dentin }\end{array}$ & 6 & 2.8 & 4 & 1.4 \\
$\begin{array}{c}\text { Kelainan } \\
\text { Pulpa }\end{array}$ & 74 & 34.4 & 95 & 34.4 \\
Abses/KMA & 135 & 62.8 & 177 & 64.1 \\
\hline Total & $\mathbf{2 1 5}$ & $\mathbf{1 0 0}$ & $\mathbf{2 7 6}$ & $\mathbf{1 0 0}$ \\
\hline
\end{tabular}

Data pada tabel 4 menunjukkan bahwa distribusi kunjungan penyakit karies gigi berdasarkan kasus tahun 2017 dengan kasus Karies Dentin berjumlah 6 orang (2,8\%), Kelainan Pulpa berjumlah 74 orang $(34,4 \%)$, kasus Abses/KMA berjumlah 135 (62,8\%) dan tahun 2018 dengan kasus Karies Dentin berjumlah 4 orang $(1,4 \%)$, Kelainan Pulpa berjumlah 95 orang $(34,4 \%)$, kasus Abses/KMA berjumlah 177 (64,1).

\section{PEMBAHASAN}

Hasil penelitian yang dilakukan di Puskesmas Sagerat Kota Bitung berdasarkan data pada tabel 1 menunjukkan bahwa jumlah penyakit karies gigi pada Tahun 2017 sebanyak 215 orang (43,8\%), Tahun 2018 sebanyak 276 orang $(56,3 \%)$. Dari data yang ada telah menunjukkan bahwa setiap tahun terjadi peningkatan jumlah kunjungan penyakit karies gigi di poliklinik gigi. Dengan meningkatnya jumlah kunjungan penyakit karies gigi di Puskesmas Sagerat Kota Bitung dalam setiap tahunnya, menunjukkan bahwa kesadaran masyarakat tentang kesehatan gigi dan mulut lebih khususnya penyakit karies gigi semakin meningkat pula. Hal ini terjadi karena ditunjang dengan pendidikan kesehatan yang sering dilakukan oleh tenaga kesehatan melalui penyuluhan dan media-media tentang kesehatan gigi dan mulut, sehingga masyarakat khususnya pasien mempunyai peningkatan pengetahuanya tentang kesehatan gigi dan mulut sehingga akhirnya mempunyai kesadaran untuk meninggalkan kebiasaan melakukan pengobatan sendiri lewat mengkonsumsi obat warung untuk menghilangkan rasa sakit gigi yang dideritanya dan mau untuk mengobati dan merawat penyakit khususnya karies gigi ke tenaga kesehatan gigi di pelayanan poliklinik gigi.

Usia yang semakin bertambah maka kejadian karies gigi lebih meningkat. Umur yang semakin tua menyebabkan waktu paparan makanan yang mengandung gula yang bersifat kariogenik terhadap gigi semakin lama, apabila didukung kebersihan gig dan mulut yang buruk sehingga karies gigi mudah terbentuk. ${ }^{4}$

Usia selalu terkait dengan masalah kesehatan gigi dan mulut terutama karies gigi. Hasil data penelitian pada tabel 2 menunjukkan bahwa distribusi penderita karies gigi tahun 2017 yang tertinggi yaitu pada kelompok umur $31 \mathrm{~s} / \mathrm{d}$ 50 tahun sebanyak 94 orang $(43,8 \%)$ dan tahun 2018 pada kelompok umur 31 s/d 50 tahun sebanyak 120 orang $(43,5 \%)$, jadi selang selama dua tahun jumlah penyakit karies gigi berdasarkan umur terbanyak ada pada umur 31 s/d 50 tahun. Usia yang semakin bertambah maka kemungkinan terjadinya karies gigi semakin meningkat, hal ini disebabkan karena usia ini adalah usia yang produktif dimana tugas pekerjaan yang lebih banyak di lakukan di luar rumah seringkali menyebabkan terabainya kebersihan gigi dan mulut seseorang karena waktu menyikat gigi yang kurang tepat dan mau berobat ke pelayanan kesehatan gigi jika sudah ada keluhan sakit.

Prevalensi karies gigi berdasarkan jenis kelamin paling banyak terjadi pada jenis kelamin perempuan. Karena masa erupsi gigi pada perempuan lebih cepat dibandingkan dengan lakilaki. Sehingga gigi lebih lama terpapar oleh makanan kariogenik dan pada masa pubertas atau pada masa kehamilan dapat terjadi pembengkakan gusi yang mengakibatkan sisa 
makanan sukar dibersihkan sehingga persentase karies gigi meningkat pada saat itu. ${ }^{5}$

Berdasarkan data pada tabel 3 menunjukkan bahwa penderita karies gigi tahun 2017 yang tertinggi adalah pada jenis kelamin perempuan yaitu sebanyak 116 orang (54\%) dan pada tahun 2018 juga yang tertinggi pada jenis kelamin Perempuan sebanyak 162 orang $(58,7 \%)$, jadi selang dua tahun jumlah penyakit karies gigi berdasarkan jenis kelamin yang terbanyak pada jenis kelamin Perempuan. Hal ini menunjukkan bahwa selain faktor usia yang mempengaruhi terjadinya penyakit karies gigi, faktor jenis kelamin juga sangat mempengaruhi terjadinya karies gigi. Dimana perempuan lebih suka mengkonsumsi makanan yang manis dan mudah melekat serta kurang menjaga kebersihan gigi dan mulutnya. Perempuan mengalami masa erupsi gigi yang lebih cepat dibanding dengan laki-laki, sehingga gigi lebih lama terpapar oleh makanan kariogenik, dan juga perempuan dipengaruhi dengan masa pubertas dan masa kehamilan. Dimana seorang ibu yang sedang hamil membutuhkan nutrisi lebih meningkat dua kali lipat dari biasanya karena dibutuhkan untuk tumbuh kembangnya janin dalam kandungannya. Dan pada masa kehamilan inilah didapatkan sebagian besar ibu hamil seringkali mengabaikan kebersihan gigi dan mulutnya karena proses kehamilan yang dialaminya.

Karies gigi adalah suatu penyakit jaringan gigi yang ditandai dengan kerusakan jaringan dimulai dari permukaan gigi (pit, fissure dan daerah interproximal) dan meluas kearah pulpa. ${ }^{6}$ Karies merupakan suatu penyakit pada jaringan keras gigi yang disebabkan oleh fermentasi jasad renik dalam suatu karbohidrat yang dapat diragikan $^{7}$

Berdasarkan data pada tabel 4 menunjukkan bahwa distribusi kunjungan penderita berdasarkan kasus karies gigi tahun 2017 yang tertinggi adalah kasus abses/KMA sebanyak 135 kasus $(62,8 \%)$ dan tahun 2018 sebanyak 177 kasus abses/KMA (64,1\%), jadi dari data penyakit karies gigi berdasarkan kasusnya selang selama dua tahun yang terbanyak pada kasus abses/KMA. Penyakit karies gigi pada stadium yang sangat dini proses ini masih dapat dihentikan dengan cara melakukan penambalan gigi, sehingga gigi bisa kembali ke fungsinya semula dan bisa mempertahankan gigi selama mungkin di dalam mulut. Namun pada stadium tertentu penyakit karies gigi dengan kasus abses/KMA, kasus yang terbanyak di poliklinik gigi Puskesmas Sagerat, menunjukkan bahwa penyakit karies gigi pada stadium ini sudah tidak dapat dihentikan kerusakannya karena sudah menyebar sampai ke jaringan di sekitar gigi yaitu gusi dan sudah menimbulkan peradangan sehingga harus memerlukan perawatan khusus. Namun jika kasusnya semakin parah dan mahkota gigi sudah tidak memungkinkan lagi, maka jalan satu-satunya dan terbaik adalah gigi tersebut harus dicabut.

Hilangnya satu atau beberapa gigi dapat menyebabkan migrasi dan rotasi gigi, hilangnya kesinambungan pada lengkung gigi sehingga menyebabkan pergeseran, miring atau berputarnya gigi. Karena gigi sudah tidak menempati posisi yang normal untuk menerima beban yang terjadi pada saat pengunyahan sehingga pada akhirnya dapat merusak struktur periodontal serta gigi yang dalam posisi miring sangat sulit dibersihkan, sehingga menyebabkan aktivitas karies meningkat pada daerah tersebut dan pada akhirnya menyebabkan terjadinya penyakit karies gigi. ${ }^{8}$

\section{KESIMPULAN}

Berdasarkan hasil dari penelitian dan pembahasan, diketahui bahwa pada rentan umur 21-40 tahun terutama pada wanita sudah melakukan gosok gigi minimal 2x sehari secara teratur namun ada beberapa yang masih memiliki kategori yang buruk karena mengabaikan kebersihan gigi dan mulut. 


\section{SARAN}

Setelah melaksanakan penelitian dan membahas hasil penelitian ini, maka peneliti dapat memberikan saran yaitu :

1. Bagi petugas poliklinik gigi Puskesmas Sagerat Kota Bitung untuk dapat meningkatkan pelayanan melalui pendidikan kesehatan gigi dan mulut (penyuluhan) kepada setiap pengunjung Puskesmas melalui ceramah atau media-media yang berisikan pesan tentang kesehatan gigi dan mulut khususnya yang berhubungan dengan penyakit karies gigi, yang diletakkan disekitar ruang tunggu pasien atau di tempat yang mudah dijangkau oleh pengunjung.

2. Untuk peneliti selanjutnya diharapkan dapat melakukan penelitian untuk variabel yang belum diteliti yang berhubungan dengan penyakit karies gigi.

\section{DAFTAR PUSTAKA}

1. Putri, H.P, Herijulianti, E, \& Nurjanah, N. (2010). Ilmu Pencegahan Penyakit Jaringan Keras Gigi dan Jaringan Pendukung Gigi. EGC. Jakarta

2. Kementerian Kesehatan RI, (2018). Riset Kesehatan Dasar. Badan Penelitian dan Pengembangan Tenaga Kesehatan Kemenkes. Jakarta

3. Herijulianti, E., Indriani, T.S., \& Artini, S. (2001). Pendidikan Kesehatan Gigi. EGC, Jakarta.

4. Sihombing, J. (2009). Karakteristik Penderita Karies Gigi Yang Berobat di Rumah Sakit Umum Dr. Pirngadi Medan. Skripsi.Program Pasca Sarjana Universitas Sumatera Utara, Medan.
5. Tarigan, R. (1995). Memelihara Kesehatan Gigi Dan Mulut. EGC, Jakarta.

6. Jakarta. .,(2013). Karies Gigi Edisi 2. EGC.

7. Putong, R.D.C, Wowor, V.N.S, \& Wicaksono, D.A. (2013). Gambaran Karies dan Kebutuhan Perawatan Restorasi Pada Masyarakat di Kelurahan Papusungan Kecamatan Lembeh Selatan. Jurnal e-GIGI vol 1. No 2 (2013)

8. Siagian, K.V. (2016). Kehilangan Sebagian Gigi Pada Rongga Mulut. Jurnal e-Clinic (eCI) Vol.4 No.1 